\title{
An Analysis of the Public Product Attribute: the Higher Education for the \\ Disabled
}

\author{
Lu YU ${ }^{1, a *}$, Qiang $\mathrm{LI}^{2, \mathrm{~b}}$ \\ ${ }^{1}$ School of Law and Politics Tianjin University of Technology, Tianjin, China \\ ${ }^{2}$ School of Law and Politics Tianjin University of Technology, Tianjin, China \\ astepfighter@163.com,'lylq@tjut.edu.com
}

Keywords: Higher education; The disabled; Public product; External effects; Attribute.

\begin{abstract}
Higher education for the disabled is a part of the special education in our country. The development of higher education of disabled people cannot do without the state's policy and financial support, the theoretical basis and the logical origin is the public goods attribute of higher education for the disabled itself. The rapid development of higher education for disabled people need the regulation and management of government departments, and the attribute of public products of higher education for the disabled is one of the logical origin of government regulation. In this paper, analysis of product attributes of higher education from two aspects --- the attribute of public product and main supply of them, concluding that the higher education for the disabled has the attribute of public products and is considered as a quasi public product. The nature of quasi public goods means that the public nature is primary for higher education for the disabled. The government should play a leading role in the supply of it.
\end{abstract}

\section{Introduction}

Higher education for the disabled is an education after disorder individual to accept in secondary school, including access to the university education and the establishment of basic education in the middle of the various types of occupation and technology education. Production and development of higher special education for the disabled is the inexorable law of development of society and education. The development of higher education is helpful to have an equal access to education, training, developing potential and the healthy development of the personality function of the disabled.

Higher education for the disabled is a part of the special education in our country. It is also an important part of the development of the cause of the disabled in China. In recent years, the country has vigorously advanced higher education for disabled people, showing the development trend of the equal right of education. People with higher education enable them to participate in social life, explore their potentials and achieve their goals in better life. It is of great advantage to create a fair social environment and construct harmonious society.

The development of higher education of disabled people cannot do without the state's policy and financial support, the theoretical basis and the logical origin is the public goods attribute of higher education for the disabled itself. At present the research on higher education for the disabled mainly focus on the current situation and problems of the development, research on the actual process of 
higher education for the disabled, but lack of research for the attribute and the supply of higher education for the disabled this product research. This is because the product attributes of higher education itself is not clearly defined; on the other hand, because of higher education for the disabled in China is still in the initial stage of development, and there are less in the number of schools and in the disabled students, study therefore focuses more on empirical.

\section{The Summary of Public Product}

Public product is relative to the private product. The classical definition according to American economist Paul A Samuelson is that the public product is "the commodity utility extension others with zero cost; cannot exclude others participate in sharing" products. The marginal cost of public goods is equal to the marginal revenue, are zero, which means that the increase in production is not the product to bring extra income.

The characteristics of public product. The definition of Samuelson pointed out two main features of public goods: non exclusive and non competitive. Non competitive refers to the influence of some product the expense not others on the consumption of the product, there is no conflict of interest between the return object; Non excludability refers to the part of the people of a certain product consumption will not rule out for other people to use and consumption of the product.

In addition, the public product is also closely linked with the positive externalities. The supply of public goods makes the related individuals or groups benefit without any fee, at the same time, people's consumption of public goods is beneficial to the surrounding environment or the whole social benefit. Therefore, the positive externalities are one of the important reasons of public sector regulation.

The judgment standard of public product. According to Samuelson's definition of public goods, whether a product is public product mainly based on its characteristics of non exclusive and non competitive. According to Buchanan in 1965 'Club of the economic theory' in the concept of public goods that as long as the decision is a collective or social groups, for some reason by the collective organization of goods or services, which can be called public goods. In fact, I think the two criterions which have a close relationship that supply mode is further deduction for product attributes. But in the presence of multi subject in market economy, product attributes and cannot simply decide the supply mode. Therefore, these two criteria are discussed, as the evaluation of higher education for the disabled product attribute reference. In addition, the product is external effect of public welfare should also be as an important standard of judging the public products. Arthur Cecil Pigou has said in his famous book Welfare Economics in the first external concepts, and thus distinguish between the social net product (close to pure public goods) and the personal net product (close to pure private goods ), in fact, the distinction between public goods and positioning considerations provide a new measure, namely the public properties of a product with positive external effects are related.

\section{Analysis of the product attributes of higher education for the disabled}

Attributes of higher education for the disabled. Higher education for the disabled is a special form of education, public welfare of education is the most important feature. Public higher education for the disabled is more obvious, the purpose is not to pursue interests, but in order to meet the needs for continuing education of disabled persons, mining the knowledge potential, improve the ability to adapt to society and social satisfaction, realize the social fair justice. 
The external effect of higher education for the disabled is the logical origin of the public. The externality of higher education for the disabled is mainly manifested in two aspects: economic benefit and social benefit. From the perspective of human resources, higher education of the disabled man to be able to train more high-quality personnel, the formation of special human capital, to increase the national income, promoting economic development is a positive impact; In addition the disabled to raise the level of education also helps the disabled this group to participate in the democratic life, reduce the social medical, unemployment compensation benefits, provide more and better public services.

From the exclusive perspective, higher education for the disabled do not have mandatory law which different from compulsory education, which means that not everyone who want to take part in the higher education of disabled people can get what they want. It says, higher education for the disabled is the threshold for admission to higher education. The main basis elements are learning needs to have a certain degree of culture, type of disability and the disability degree. From the real point of view, the higher school in our country at present for disabled people will hold some form of entrance examination. In fairness based on test scores are exclusive and easy to be accepted by the society.

From the competition point of view, due to the development of higher education for the disabled in China is still at the low level, higher education for the disabled school quantity is limited, teachers, equipment and other hardware and software cannot fully meet the increasing demand for higher education, therefore higher education for the disabled is crowd. So far, higher education for the disabled is a scarce resource. As long as there is the opportunity to enter the competition, there is competition relative. In a sense, exclusive because there is competition, and the threshold selection affects the degree of competition exclusion means setting.

The main supply of higher education for the disabled. The positive externality of higher education for the disabled to society is the fundamental reason for the national investment supply. It is because of higher education for the disabled only for disabled students to improve their own quality, better adapt to social help, at the same time also has a positive significance for the whole society. From a realistic point of view, in some places at present our country higher education for the disabled, its funds mainly come from government subsidies. Compared to the obvious private nature of the product in some private universities and elite schools, the non-profit nature of higher education for the disabled school is very prominent. That is to say, from the supply point of view, higher education for the disabled is a public product.

\section{Conclusion}

From the attributes of product point of view, at the present stage the higher education is a limited competitive and exclusive products and services; However the obvious positive externality determine higher education for the disabled is a great business that benefit to the whole country and society, thus has the very strong public welfare. From the supply point of view, at present our country higher education institutions are public institutions for disabled people, money is the main source of national finance. In general, higher education for the disabled in this stage belongs to quasi public product.

The nature of quasi public goods means that the public nature is primary for higher education for the disabled. The government should play a leading role in the supply of it. On the other hand, the situation of a certain degree competition and exclusion on benefit also explain that the shortage stage 
of China's government supply of higher education for the disabled. Higher education of the disabled has scale effect similar to higher education, enrollment increased to accelerate the expansion of educational cost pressure, at the same time, the higher education for the disabled cost is much higher than the ordinary higher education for its specific characteristics. Cost pressures and supply - demand contradictions become the shackles of the further development of higher education for the disabled. In this case, analysis of the nature of higher education for the disabled, feasibility analysis will be based on the introduction of private capital and even the third party intervention in higher education for the disabled to lay the foundation. In order to put forward some feasible solutions to solve problems like the shortage of funds of higher education for the disabled.

\section{References}

[1] Fan Mingyong, Public Economics [M], Shanghai: Fudan University Press, 2001.

[2] Huang Hengxu, Public Eeconomics[M],Beijing:Peking University Press,2002.

[3] Pat ricia L . Sitlington. Post secondary Education: the other tansition. Except ionality, 2003, 11( 2) :103-113.

[4] Li Yining, About the Nature of Education and Educational Products Business[J], Research in Education Development,1999,10:9-14.

[5] Wu Hongjun,Li Qiang, Developing the High Education Theory and Practice of the Disabled in China[J], Chinese Journal of Special Education,2005,(1):10-15.

[6] Huang Jingmei, Wang Aiguo, An Analysis of the Problems in Development of Chinese Higher Education for the Disabled[J], Chinese Journal of Special Education,2008,(12):74-77.

[7] $\mathrm{Ma} \mathrm{Yu,} \mathrm{An} \mathrm{Exploration} \mathrm{on} \mathrm{Problems} \mathrm{in} \mathrm{the} \mathrm{Development} \mathrm{of} \mathrm{Higher} \mathrm{Education} \mathrm{for} \mathrm{the} \mathrm{Disabled}$ in China[J],Modern Education Science,2012,(5):147-149.

[8] Lv Shuhui,Teng Xiangdong,Hao Chuanping, An Exploration on Higher Education for Students with Disabilities in China[J], Disability Research,2012,(1):54-57.

[9] Ma Yiqing,Sun Ying, The Present Higher Education for Disabled Persons

in China and Relevant Problems[J], Chinese Journal of Special Education,2012,(7):19-24.

[10] Gao Lianhe, Yang Li,The Balance between Higher Education's Character of Public Product and Marketing[J],Vocational and Technical Eduction,2005,(10):13-15.

[11] Yang Jupeng,Deng Zhengrong, The Economic Research on How the Choice System of Educational Consumers Affects the Supply of High Education Service in China-From the View of the Produce-consumer Theory[J], Tsinghua Journal of Education,2012,6(3):83-88.

[12] Wang Yelin, Thinking about the Attributes of Public Goods and Externality[J],Economic Vision,2011,(11):113-114.

[13] Jia Jingquan, The Supply Path of Countryside Fundamental Education in the Angle of Public Product[J], Journal of Fuyang Teachers College,2008,(3):125-127.

[14] Yang Ruting, Quasi Public Product of Higher Education and Its Supply[J],Journal of Higher Education Management,2009,(5):21-25. 